\title{
PENGARUH PENCAHAYAAN TERHADAP PENULARAN PENYAKIT ISPA DI WILAYAH PUSKESMAS BANTARKAWUNG
}

\author{
THE EFFECT OF LIGHTING ON ISPA DISEASE IN BANTARKAWUNG PUSKESMAS
}

\author{
Luthfi Hidayat Maulana
}

Fakultas Sains dan Teknologi Universitas Peradaban

Jl. Raya Pagojengan Km.3 PaguyanganBrebes - Jawa Tengah

Email : luthfihidayat578@gmail.com

\begin{abstract}
According to the World Health Organization (WHO) estimates the incidence of ARI in developing countries is $0.29 \%$ (151 million people) and in industrialized countries $0.05 \%$ (5 million people) (WHO, 2012) Where Acute Respiratory Infection (ARI) is one the main cause of death by killing \pm 4 million of 13 million children under five every year. The purpose of this study was to determine whether there is an effect of lighting on the transmission of ARI in the area of Puskesmas Bantarkawung. This research uses the Cross-Sectional survey method. There were 78 respondents who were sampled as families of ARI sufferers. This study uses univariate analysis to describe the characteristics of research variables with a frequency distribution table with lighting factors. After that, the analysis was followed by linear regression analysis to determine the effect of lighting on the transmission of ARI. The results of this study indicate that (1) home lighting in the Puskesmas Bantarkawung area of Brebes Regency the proportion based on the most room lighting is $76.9 \%$ under lighting category (2) There is the effect of lighting with an increased risk of ISPA transmission by 1,907 times.
\end{abstract}

\section{Keywords: lightning; ARI}

\begin{abstract}
ABSTRAK
Menurut World Health Organization (WHO) memperkirakan insidensi ISPA di negara berkembang 0,29\% (151 juta jiwa) dan negara industri 0,05\% (5 juta jiwa) (WHO, 2012) Dimana Infeksi Saluran Pernapasan Akut (ISPA) merupakan salah satu penyebab utama kematian dengan membunuh \pm 4 juta dari 13 juta anak balita setiap tahun. Tujuan penelitian ini adalah mengetahui apakah ada pengaruh pencahayaan terhadap penularan penyakit ISPA di wilayah puskesmas Bantarkawung. Penelitian ini menggunakan metode survei Cross Sectional. Ada 78 responden yang dijadikan sampel keluarga penderita ISPA. Penelitian ini menggunakan analisis univariat untuk menggambarkan karakteristik variabel penelitian dengan tabel distribusi frekuensi dengan faktor pencahayaan. Analisis regresi linear untuk mengetahui pengaruh pencahayaan terhadap penularan penyakit ISPA. Hasil penelitian ini menunjukan bahwa (1) Pencahayaan rumah di wilayah Puskesmas Bantarkawung Kabupaten Brebes proporsi berdasarkan pencahayaan ruangan terbanyak adalah kategori pencahayaan kurang sebanyak $76,9 \%$ rumah penderita (2) Ada pengaruh pencahayaan dengan peningkatan risiko terhadap penularan ISPA sebesar 1,907 kali.
\end{abstract}

Kata kunci : Pencahayaan; ISPA 


\section{PENDAHULUAN}

World Health Organization (WHO) memperkirakan insidensi ISPA di negara berkembang 0,29\% (151 juta jiwa) dan negara industri 0,05\% (5 juta jiwa) (1). Dimana Infeksi Saluran Pernapasan Akut (ISPA) merupakan salah satu penyebab utama kematian dengan membunuh \pm 4 juta dari 13 juta anak balita setiap tahun. Hal yang serupa juga terjadi di Indonesia. Berdasarkan prevalensi ISPA tahun 2016 di Indonesia telah mencapai $25 \%$ dengan rentang kejadian yaitu sekitar $17,5 \%-41,4 \%$ dengan 16 provinsi diantaranya mempunyai prevalensi di atas angka nasional. Prevalensi terjadinya ISPA di Propinsi Jawa Tengah pada tahun 2017 menduduki peringkat kedelapan di Indonesia dengan angka kejadian sebesar 53,7\% dimana penyakit tersebut merupakan 10 besar penyakit yang ditangani (2).

Berdasarkan data dari Dinas Kesehatan Kabupaten Brebes angka penderita ISPA sampai dengan Bulan Oktober 2019 sudah mencapai 2.738 penderita atau sekitar 45,05\%. Banyaknya penderita ISPA di Kabupeten Brebes, disebabkan karena sistem pertahanan tubuh balita yang masih rendah. Sedangkan menurut data riset kesehatan dasar (Riskesdas) tahun 2018 dinyatakan bahwa periode prevalensi nasional ISPA di Indonesia berdasarkan diagnosis tenaga kesehatan dan gejala yaitu 9,3\% Dan persentase ini menurun jika dibandingkan dengan periode prevalensi ISPA pada tahun 2013 yaitu sebesar $25 \%$ (3).

Selain itu, penelitian yang berhubungan dengan tingginya penyakit ISPA di Indonesia menunjukkan ada beberapa faktor yang mempengaruhi penyakit tersebut di antaranya seperti: status ekonomi, lingkungan di dalam rumah yang kurang memadai berupa kurang higienisnya lantai yang masih dalam kondisi berupa tanah atau tidak terbuat dari keramik, kurangnya pencahaayaan yang masuk kerumah, ventilasi udara yang bertolak belakang dengan kesesuaian dimana luas ventilasi udara dibawah standar ukuran luas area tiap ruangan, jumlah hunian yang melebihi standar kapasitas ruangan sehingga menimbulkan kelembaban udara tinggi, adanya binatang peliharaan di dalam rumah serta status merokok dalam rumah (4)(5)(6).

Hasil observasi awal di wilayah kerja Puskesmas Bantarkawung pada bulan Desember 2019, kebanyakan kurang cahaya matahari langsung maupun cahaya buatan menyebabkan virus dan bakteri dapat bertahan hidup selama 14 hari(7). Kondisi bakteri dan virus yang bertahan selama 14 hari dan rumah padat hunian mempunyai peluang besar untuk menimbulkan kasus baru dalam satu rumah. Tujuan penelitian ini adalah mengetahui apakah ada pengaruh pencahayaan terhadap penularan penyakit ISPA di wilayah puskesmas Bantarkawung.

\section{BAHAN DAN METODE}

Jenis penelitian yang digunakan adalah penelitian penjelasan (explanatori research) karena ingin menjelaskan pengaruh antara dua variabel melalui pengujian hipotesa. Metode penelitian yang dipakai adalah metode survei dengan pendekatan Cross Sectional. Populasi yang akan diteliti adalah penderita ISPA yang tercatat dalam rekam medik berdasarkan hasil pemeriksaan pada laboratorium dan pemeriksaan dokter Puskesmas sebanyak 1.394 responden. Sampel yang akan diteliti adalah random sampling, yaitu keluarga penderita ISPA yang memiliki pencahayaan rumah kurang baik sebanyak 78 responden. Data yang sudah terkumpul dilakukan pemeriksaan/ validasi data, pengkodean dan rekapitulasi, kemudian dilakukan analisis statistik sebagai berikut yang pertama Analisis univariat adalah analisis yang digunakan untuk menganalisis setiap variabel dari hasil penelitian (8)(9). Analisis univariat bertujuan untuk mendiskripsikan karakteristik masing-masing variabel penelitian melalui tabel distribusi frekuensi, pada pencahayaan rumah penderita penyakit ISPA kemudian dilanjutkan menggunakan uji regresi linear dengan tujuan untuk mengetahui pengaruh pencahayaan terhadap kejadian penularan penyakit ISPA pada keluarga.

\section{HASIL DAN PEMBAHASAN}

\section{Hasil Penelitian}

Kondisi pencahayaan pada rumah penderita ISPA Distribusi pencahayaan di wilayah Puskesmas Bantarkawung Kabupaten Brebes proporsi berdasarkan pencahayaan ruangan terbanyak adalah katagori pencahayaan kurang sebanyak 60 rumah penderita $(76,9 \%)$, katagori pencahayaan baik sebanyak 14 rumah penderita $(17,9 \%)$, dan katagori pencahayaan sangat baik sebanyak 4 rumah penderita $(5,1 \%)$. Pencahayaan kurang persentasinya paling tinggi, kondisi tersebut menyebabkan virus dan bakteri dapat berkembangbiak dengan baik (Tabel 1). 


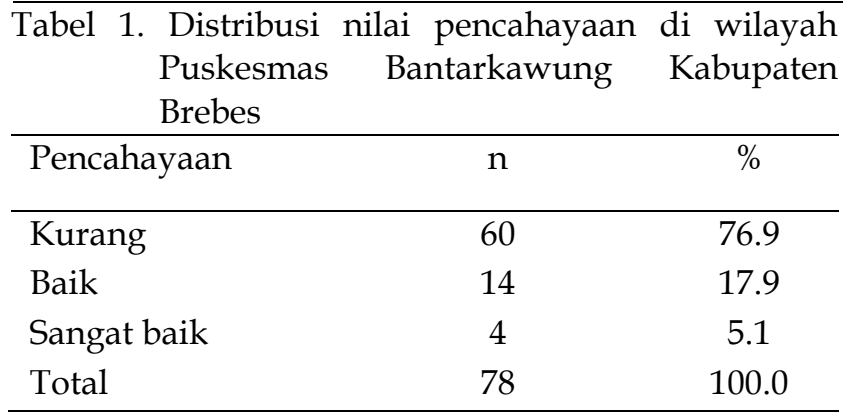

\section{Pengaruh pencahayaan terhadap kejadian penularan ISPA pada keluarga}

Tabel 2. Hasil analisis regresi pengaruh pencahayaan terhadap kejadian penularan ISPA pada keluarga

\begin{tabular}{llll}
\hline \multicolumn{1}{c}{ Variabel } & $\begin{array}{c}\text { Koefisien } \\
\text { Regresi }\end{array}$ & Sig. & $\operatorname{Exp}(\mathrm{B})$ \\
\hline Pencahayaan & 1,907 & 0,000 & 6,734 \\
Constant & $-4,251$ & 0,000 & 0,014 \\
\hline
\end{tabular}

Persamaan regresi linear dapat dilihat sebagai berikut:

$$
\begin{aligned}
& Y=\text { Constanta }+X_{1} \\
& Y=-5,948+1,907 X_{1}
\end{aligned}
$$

Keterangan:

$\mathrm{X}_{1}=$ Pencahayaan

$\mathrm{Y}=$ Kejadian penularan

\section{PEMBAHASAN}

Berdasarkan persamaan regresi tersebut, bahwa setiap penurunan pencahayaan $1 \%$ akan meningkatkan risiko penularan ISPA sebesar 1,907 kali. Hasil penelitian tersebut menunjukan bahwa hasil analisis statistik dengan menggunakan uji $\mathrm{X}^{2}$ diperoleh nilai $p$ value $=0,000<\alpha(0,05)$, yang artinya pencahayaan dalam rumah penderita ISPA yang tidak memenuhi persyaratan kesehatan berpengaruh dengan kejadian penularan ISPA pada keluarga.

Pencahayaan pada rumah tinggal penderita ISPA yang tidak memenuhi persyaratan kesehatan mempunyai risiko penularan kepada keluarganya. Risiko penularan ISPA masih terjadi karena masyarakat belum banyak yang mengetahui cara pencegahan diantaranya dengan membuat ventilasi rumah berupa lubang angin dan jendela serta genteng kaca yang memenuhi syarat kesehatan untuk masuknya sinar matahari secara langsung. Sinar matahari mengandung ultra violet yang mempunyai kemampuan membunuh kuman (10). Hasil penelitian tersebut sejalan dengan pendapat Deta (2010) yang menyebutkan bahwa pencahayaan merupakan salah satu faktor risiko kejadian penularan ISPA (11). Menurut Keputusan Menteri Kesehatan Republik Indonesia, Nomor 829/MENKES/SK/VII/1999 Tentang Persyaratan Kesehatan Perumahan disebutkan bahwa pencahayaan adalah pencahayaan alami dan/atau buatan langsung maupun tidak langsung dapat menerangi seluruh ruang minimal 60 lux dan tidak menyilaukan (12).

Jendela kamar tidur merupakan faktor risiko terjadinya penyakit ISPA. Risiko untuk menderita ISPA 6-7 kali lebih tinggi pada penduduk yang tinggal dengan kondisi rumah tidak mempunyai jendela kamar tidur. Kamar tidur sebaiknya diletakan disebelah timur untuk memberi kesempatan masuknya sinar ultraviolet yang ada dalam sinar matahari pagi (13). Menurut I Gede et al (2015), fungsi jendela kamar tidur adalah pertama, agar sinar matahari dapat masuk kedalam kamar dan membunuh kuman penyakit. Kedua, agar kamar menjadi terang sehingga mudah dibersihkan. Ketiga agar udara kotor dalam kamar dapat berganti dengan udara yang bersih dari luar. Keempat, agar kamar tidak menjadi lembab dan berbau tidak enak (14).

Jendela ruang keluarga merupakan faktor risiko terjadinya penyakit ISPA. Risiko untuk menderita ISPA 7-8 kali lebih tinggi pada penduduk yang tinggal pada rumah yang tidak memiliki jendela ruang keluarganya. Sebagian besar waktu penderita dihabiskan diruang keluarga, apabila tidak ada jendela maka ruangan tersebut akan lembab. Hal ini berakibat memperpanjang masa viabilitas kuman ISPA yang menyebabkan potensi penularan ISPA lebih besar (15).

\section{KESIMPULAN DAN SARAN}

Ada pengaruh pencahayaan dengan peningkatan risiko terhadap penularan ISPA sebesar 1,907 kali. proporsi berdasarkan pencahayaan ruangan terbanyak adalah kategori pencahayaan kurang sebanyak $76,9 \%$ rumah penderita. Adapun Saran Peneliti lain dapat lebih mengembangkan sumber penularan dari faktor lingkungan untuk menemukan hasil yang lebih akurat. Bagi Penderita lebih baik dibuatkan jendela dan genteng kaca agar sinar matahari dapat masuk dan sirkulasi udara lebih baik. Bagi Institusi kesehatan harus sering terjun ke lapangan untuk memberikan penyuluhan, supaya masyarakat memahami cara pencegahan penyakit ISPA. Bagi Masyarakat harus membuat rumah yang berstandar sehat untuk menghindari segala jenis penyakit, salah satunya ISPA.

\section{DAFTAR PUSTAKA}

1. World Health Organization (WHO). World Health Statistics 2015 [Internet]. 
www.who.int. Geneva: WHO Press; 2015 [cited 2020 Apr 9]. Available from: http://www.who.int/gho/publications/worl d_health_statistics/en/

2. Departemen Kesehatan. Pedoman Nasional Penanggulangan Infeksi Saluran Pernapasan Akut. In: Cetakan ke. Departemen Kesehatan Republik Indonesia; 2014.

3. Widyawati. Potret Kesehatan Indonesia dari Riskesdas $2018 \quad$ [Internet]. www.kemenkes.go.id. 2018 [cited 2020 Apr 7]. Available from: http:/ / sehatnegeriku.kemkes.go.id/baca/rilis -media/20181102/0328464/potret-sehatindonesia-riskesdas-2018/

4. Kunoli FJ. Pengantar Epidemiologi Penyakit Menular : Untuk Mahasiswa Kesehatan Masyarakat. Jakarta: CV. Trans Info Media; 2013.

5. Christi H, P DR, Nugraheni SA. Faktor Faktor Yang Berhubungan Dengan Kejadian Ispa Pada Bayi Usia 6-12 Bulan Yang Memiliki Status Gizi Normal. J Kesehat Masy. 2015;3(2).

6. Firnanda N. Analisis Spasial Kejadian Penyakit Infeksi Saluran Pernapasan Akut (Ispa) Pada Balita Di Kelurahan Puwatu. Jimkesmas J Ilm Mhs Kesehat Masy. 2017;2(7).

7. Dinas Kesehatan Kabupaten Brebes. Profil Kesehatan Kabupaten Brebes Tahun 2019. Dinas Kesehatan Kabupaten Brebes; 2019.

8. Notoatmodjo S. Ilmu Kesehatan Masyarakat Prinsip-Prinsip Dasar. Jakarta: PT. Rineka Cipta; 2013.

9. Iqbal MW, Chayatin N. Ilmu Kesehatan Masyarakat: Teori Dan Aplikasi. Jakarta: Salemba Medika; 2009.

10. Ristanti FF. Pengaruh Kondisi Sanitasi Rumah Terhadap Kejadian Ispa Di Kecamatan Wiyung Kota Surabaya. Universitas Negeri Surabaya; 2012.

11. Dewanti AD, Suharni, Warsiti. Hubungan Kondisi Kesehatan Lingkungan Rumah Dengan Kejadian ISPA Pada Balita Di Desa Umbul Martani Wilayah Kerja Puskesmas Ngemplak 1 Sleman Yogyakarta Tahun 2010. Universitas 'Aisyiyah Yogyakarta (UNISA); 2010.

12. Keputusan Menteri Kesehatan RI. Persyaratan Kesehatan Perumahan. 829/MENKES/SK/VII/1999 Indonesia; 1999.

13. Prajwalita MK. Pengaruh Sanitasi Rumah dan Polusi Udara Terhadap Kejadian Infeksi Saluran Pernafasan Akut (ISPA) pada Balita di Kecamatan Ngariboyo Kabupaten Magetan. Swara Bhumi e-Journal Pendidik Geogr FIS Unesa. 2016;4(1).

14. Gapar IGS, Adiputra N, Pujaastawa IBG.
Hubungan Kualitas Sanitasi Rumah dengan Kejadian Penyakit Infeksi Saluran Pernapasan Akut (ISPA) di Wilayah Kerja Puskesmas IV Denpasar Selatan Kota Denpasar. J Ilmu Lingkung (Journal Environ Sci. 2015;9(2).

15. Budiman S. Ilmu Kesehatan Masyarakat Dalam Konteks Kesehatan Lingkungan. Jakarta: Buku Kedokteran EGC; 2016. 